\title{
RISK ASSESSMENT OF CHROMIUM LEVELS IN BROILER FEEDS AND MEATS FROM SELECTED FARMS OF BANGLADESH
}

\author{
M. M. Islam', S. M. L. Kabir ${ }^{\text {* }}$, Y. A. Sarker², M. M. H. Sikder², S. K. S. Islam ${ }^{3}$, A. H. M. T. Akhter ${ }^{4}$ and \\ M. M. Hossain ${ }^{3}$
}

${ }^{1}$ Department of Microbiology and Hygiene; ${ }^{2}$ Department of Pharmacology, Faculty of Veterinary Science, Bangladesh Agricultural University, Mymensingh-2202, Bangladesh; ${ }^{3}$ Epidemiology Unit, Department of Livestock Services, Krishi Khamar Sarak, Farm gate, Dhaka-1215, Bangladesh; ${ }^{4}$ FAO-Food Safety Program (FSP), Institute of Public Health, Mohakhali, Dhaka-1215, Bangladesh

\begin{abstract}
The present study was conducted to evaluate the status of chromium concentration in broiler feeds with the risk assessment of chromium in broiler meat. Seven broiler farms were selected to collect the feed and meat samples of broiler. Atomic absorption spectrophotometer (AAS) was used to determine the chromium concentration in broiler feed and meat samples. The highest concentration of chromium in broiler meat samples was $1.31 \pm 0.20 \mu \mathrm{g} / \mathrm{g}$ and in feed samples was $1.71 \pm 0.24 \mu \mathrm{g} / \mathrm{g}$. In this study, the mean ( \pm SE) concentration of chromium in feed samples from Gazipur Sadar, Gazipur; Sreepur, Gazipur and Tangail Sadar, Tangail were 1.71( \pm 0.24) $\mu \mathrm{g} / \mathrm{g}, 1.64( \pm 0.61) \mu \mathrm{g} / \mathrm{g}$ and $1.64( \pm 0.61) \mu \mathrm{g} / \mathrm{g}$ respectively. The mean $( \pm$ SE) concentration of chromium in meat samples from Gazipur Sadar, Gazipur; Sreepur, Gazipur and Tangail Sadar, Tangail were $1.139( \pm 0.26) \mu \mathrm{g} / \mathrm{g}, 1.31( \pm 0.20) \mu \mathrm{g} / \mathrm{g}$ and $0.61( \pm 0.23) \mu \mathrm{g} / \mathrm{g}$ respectively. The concentrations of chromium in broiler edible tissues were much higher than permissible levels determined by FAO and WHO. Precocious steps must be taken to avoid use of such health hazardous concentrations of heavy metals in poultry feeds. Considering these findings, there is a critical need to set legal limits and surveillance system for detection of heavy metals in poultry industry of Bangladesh.
\end{abstract}

Key words: Chromium, broiler feeds, broiler meats.

\section{INTRODUCTION}

Food safety is a major public health concern worldwide. During the last decades, the increasing demand of food safety has stimulated research regarding the risk associated with consumption of heavy metals (D'Mello, 2003). Heavy metals, in general are not biodegradable, having long biological half-lives and having the potential for accumulation in the different body organs leading to unwanted side effects (Jarup, 2003; Banerjee et al., 2011). The risk associated with the exposure to heavy metals present in food product had aroused wide spread concern in human health (Meli et al., 2015).Occasionally, mineral supplements are added to broiler feeds to fulfill the required limit. Most of the time, studies conducted on broiler feeds in India, Bangladesh, Pakistan and various other places around the world, have shown the presence of high concentration of heavy metals in broiler feeds, due to purely anthropogenic reasons (Mahmood et al., 2004; Islam et al., 2007; Sunda, 2010). Khan et al. (2005) assessed the risk of polluted and excessive amount of various ingredients used in animal feed. As far as the feed ingredients and the compound feed for poultry are an essential part of the consumer's food chain, they need to be determined as potential sources of chromium contamination. Many studies are conducted to detect the chromium from poultry feed and results showed the mixing of high concentration of heavy metals (Alkhalaf et al., 2005). When these metals are added in feed more than the required level, these can accumulate in body tissues of broiler and in human being on its consumption (McBride et al., 2001). Chromium and its compounds are also well known toxins especially chromium (VI) which due to its oxidizing potentials easily permeates biological membranes and causes renal damage, disease of the central nervous system, cancer etc. in human (Bae et al., 2001). In case of poultry industry deposition of chromium in broiler meats were result of their excessive use in poultry feed. Considering the potential risks of chromium in broiler edible tissues in Bangladesh, the present study was designed to detect chromium in broiler feed and their accumulation in body tissues.

*Corresponding e-mail address: lkabir79@gmail.com 


\section{M. Islam and others}

\section{MATERIALS AND METHODS}

\section{Sample collection}

A study was conducted at the Department of Agricultural Chemistry, Bangladesh Agricultural University, Mymensingh during the period of January 2016 to May 2016 from selected 5 broiler farms and 2 live bird markets of Gazipur Sadar and Sreepur upazilla of Gazipur district and 2 broiler farms from Tangail Sadar of Tangail district in Bangladesh. A total of 37 samples were collected from 7 broiler farms and 2 live bird markets including 30 meat samples and 7 feed samples to evaluate the intensity of chromium levels in feeds and meats of broiler. Then it was immediately brought to the Department of Agricultural Chemistry, Bangladesh Agricultural University, Mymensingh through cool chain maintaining.

\section{Sample preparation}

This process of digestion is required for spectroscopic analysis. The principle is releasing of metals from solid matrix to the acid solution during the extraction process (Koki, 2015). The concentration of total heavy metals in broiler feed and meat samples were determined at the Department of Agricultural Chemistry of Bangladesh Agricultural University, Mymensingh. According to Rashid et al. (2016) nitric and perchloric acid digestion in 2:1 ratio was used for digestion of samples. For nitric and perchloric acid digestion it is required to prepare diacid mixture by adding $100 \mathrm{ml}$ nitric acid and $50 \mathrm{ml}$ perchloric acid to produce $150 \mathrm{ml}$ preparation. Approximately $1 \mathrm{gm}$ of sample was placed in a $250 \mathrm{ml}$ of digestion tube before the addition of $10 \mathrm{ml}$ di-acid mixture. The mixture then placed on a hot plate to maintain $120^{\circ} \mathrm{C}$ temperature until the mixture become colorless. After completing the digestion, the sample kept cool at room temperature. Then the digest was filtered through a filter paper (Whatman no.42) and the filtrate volume was made up to $50 \mathrm{ml}$ with distilled water. The sample was then diluted to $100 \mathrm{ml}$ using deionised distilled water and preserved it plastic water container.

\section{Determination of chromium in broiler feed and meat by spectroscopic analysis}

The determination of chromium in extracted samples was done by using an atomic absorption spectrophotometer (AAS) (Shimadzo, AA7000, Japan). Monoelement hollow cathode lamp was employed for the determination of each heavy metal of interest. At first the AAS was calibrated followed by the manufacturer's recommendation. A standard curve was prepared by plotting the absorbance reading on Y-axis versus the concentration of each standard solution of metal on X-axis. Then, the concentration of heavy metal was calculated in the samples of interest by plotting the AAS reading on the standard curve.

\section{Statistical analysis}

Data for chromium (Cr) content of broiler feeds and meats from different locations were analyzed statistically using the SPSS (version 20.1) software. A one-way analysis of variance (ANOVA) of each variable was worked out.

\section{RESULTS AND DISCUSSION}

The chromium (Cr) concentration in collected broiler meat and feed samples are presented in Table 1 . The mean $( \pm$ SE) concentration of chromium in meat samples from Gazipur Sadar, Gazipur; Sreepur, Gazipur and Tangail Sadar, Tangail were $1.139( \pm 0.26) \mu \mathrm{g} / \mathrm{g}, 1.31( \pm 0.20) \mu \mathrm{g} / \mathrm{g}$ and $0.61( \pm 0.23) \mu \mathrm{g} / \mathrm{g}$ respectively. In this study, a total of 30 meat samples were collected from 7 broiler farms and highest concentrations of chromium $(1.31 \pm 0.20 \mu \mathrm{g} / \mathrm{g})$ were detected in Sreepur, Gazipur. The mean ( \pm SE) concentration of chromium in feed samples from Gazipur Sadar, Gazipur; Sreepur, Gazipur and Tangail Sadar, Tangail were 1.71( \pm 0.24) $\mu \mathrm{g} / \mathrm{g}, 1.64( \pm 0.61)$ $\mu \mathrm{g} / \mathrm{g}$ and 1.64( \pm 0.61$) \mu \mathrm{g} / \mathrm{g}$ respectively. A total of 7 feed samples were collected from 7 broiler farms and highest concentrations of chromium $(1.71 \pm 0.24 \mu \mathrm{g} / \mathrm{g})$ were detected in Sreepur, Gazipur. Analysis of variance shows that different placement had non- significant effect on broiler feed and meat chromium levels (Table 1). The current study was conducted to investigate the presence of chromium level in broiler feeds and meats from selected farms of Bangladesh. For the detection of the chromium concentration sample preparation, digestion and spectroscopic analysis were performed. Chromium concentration was found to be much lower than the permissible limit set by NRC, 2005 (500 ppm or $\mu \mathrm{g} / \mathrm{g}$ ). There is no permissible limit for chromium in feeding stuff given by the EU, 2003. The concentrations of chromium in broiler edible tissues were much higher than 
permissible levels determined by FAO and WHO (Choi, 2011). The current study recorded only chromium in feed and edible tissues of broiler. It is necessary to conduct a study for the screening of heavy metals that are intentionally or unintentionally introduced in broiler production.

Table 1. Concentration of Chromium (Cr) in collected broiler meat and feed samples

\begin{tabular}{|c|c|c|c|c|c|}
\hline $\begin{array}{l}\text { Type } \\
\text { Sample }\end{array}$ & of & $\begin{array}{l}\text { Sample } \\
\text { No. }\end{array}$ & Placement & $\begin{array}{l}\text { Chromium concentration ( } \\
\mu \mathrm{g} / \mathrm{g})\end{array}$ & $\begin{array}{l}\text { Mean } \\
\text { Concentration }( \pm S E)(\mu g / g)\end{array}$ \\
\hline \multirow{30}{*}{ Meat } & & 1 & \multirow{13}{*}{ Gazipur Sadar, Gazipur } & BDL & \multirow{13}{*}{$1.139( \pm 0.26)$} \\
\hline & & 2 & & 1.19 & \\
\hline & & 3 & & 2.41 & \\
\hline & & 4 & & 0.97 & \\
\hline & & 5 & & 1.68 & \\
\hline & & 6 & & 1.83 & \\
\hline & & 7 & & 2.29 & \\
\hline & & 8 & & 1.01 & \\
\hline & & 9 & & 0.86 & \\
\hline & & 10 & & BDL & \\
\hline & & 11 & & BDL & \\
\hline & & 12 & & 2.57 & \\
\hline & & 13 & & BDL & \\
\hline & & 14 & \multirow{9}{*}{ Sreepur, Gazipur } & 1.18 & \multirow{9}{*}{$1.31( \pm 0.20)$} \\
\hline & & 15 & & 1.59 & \\
\hline & & 16 & & 2.21 & \\
\hline & & 17 & & BDL & \\
\hline & & 18 & & 1.87 & \\
\hline & & 19 & & 1.16 & \\
\hline & & 20 & & 1.44 & \\
\hline & & 21 & & 1.26 & \\
\hline & & 22 & & 1.13 & \\
\hline & & 23 & \multirow{8}{*}{ Tangail Sadar, Tangail } & BDL & \multirow{8}{*}{$0.61( \pm 0.23)$} \\
\hline & & 24 & & BDL & \\
\hline & & 25 & & 1.51 & \\
\hline & & 26 & & 0.98 & \\
\hline & & 27 & & 1.18 & \\
\hline & & 28 & & BDL & \\
\hline & & 29 & & 1.22 & \\
\hline & & 30 & & BDL & \\
\hline \multirow{7}{*}{ Feed } & & 1 & \multirow{3}{*}{ Gazipur Sadar, Gazipur } & 1.37 & \multirow{3}{*}{$1.71( \pm 0.24)$} \\
\hline & & 2 & & 1.59 & \\
\hline & & 3 & & 2.18 & \\
\hline & & 4 & \multirow{2}{*}{ Sreepur, Gazipur } & 2.26 & \multirow[t]{2}{*}{$1.64( \pm 0.61)$} \\
\hline & & 5 & & 1.03 & \\
\hline & & 6 & \multirow{2}{*}{ Tangail Sadar, Tangail } & 1.28 & \multirow[t]{2}{*}{$1.175( \pm 0.11)$} \\
\hline & & 7 & & 1.07 & \\
\hline
\end{tabular}

$*$ BDL $=$ Below Detectable Limit in ppm level $(\mu \mathrm{g} / \mathrm{g})$

\section{CONCLUSIONS}

The result of this study therefore indicates that broilers raised with commercial feed have significant concentrations of chromium over the permissible FAO/WHO levels. High concentration of chromium in broiler feeds resulted in their bioaccumulation in muscle tissues of broiler. That is not only harmful for broilers itself but can also be harmful for consumers on excessive consumption.

\section{ACKNOWLEDGMENTS}

Authors would like to thank the Department of Agricultural Chemistry of Bangladesh Agricultural University, Mymensingh for providing facilities during analysis. 


\section{M. Islam and others}

\section{REFERENCES}

1. Alkhalaf NA, Osman AK and Salama K (2010). Monitoring of aflatoxins and heavy metals in some poultry feeds. African Journal of Food Science 4: 192-199.

2. Bae DS, Gennings C, Carter WH, Yang RS and Campain JA (2001). Toxicological interactions among arsenic, cadmium, chromium, and lead in human keratinocytes. Toxicological Sciences 63: 132-142.

3. Banerjee D, Kuila P, Ganguli A, Das D, Mukherjee S and Ray L (2011). Heavy metal contamination in vegetables collected from market sites of Kolkata, India. Electronic Journal of Environmental, Agricultural and Food Chemistry 10: 2160-2165.

4. Bennett JW and Klich M (2003). Mycotoxins. Clinical Microbiology 16: 497-516.

5. Choi YY (2011). International/National Standards for Heavy Metals in Food. Government Laboratory (Australia).

6. D'Mello JPF (2003). Food safety: contaminants and toxins (480). Wallingford: CABI Publishing.

7. European Commission; Health and Consumer Protection Directorate - General, Belgium (2003). Opinion of the Scientific Committee on Animal Nutrition on Undesirable Substances in Feed.

8. Islam MS, Kazi MAI, Hossain MM, Ahsan MA and Hossain AM (2007). Propagation of heavy metals in poultry feed production in Bangladesh. Bangladesh Journal of Scientific and Industrial Research 42: 465-474.

9. Jarup L (2003). Hazards of heavy metal contamination. British Medical Bulletin 68: 167-182.

10. Khan CA and Meijer GAL (2005). The risk of contamination of food with toxic substances present in animal feed. Animal Feed Science and Technology 133:84-108

11. Koki IB (2015). Efficiencies of acid digestion / leaching techniques in the determination of iron concentrations in soils from Challawa Industrial Estate Kano , Nigeria. Merit Research Journals 3: 65-71.

12. Mahmood, SN, Ahmad MA, Shamsuddin ZA, Siddiqui IU and Khan FA (2004). Metals profile of broiler poultry feeds produced in Karachi. Journal of the Chemical Society of Pakistan 26: 97-100.

13. McBride MB and Spiers G (2001). Trace element content of selected fertilizers and dairy manures as determined by ICP-MS. Communications in Soil Science and Plant Analysis 32: 139-156.

14. MeliMA, Desideri D, RoselliC, Benedetti C and Feduzi L (2015). Essential and toxic elements in honeys from a region of central Italy. Journal of Toxicology and Environmental Health 78: 617-627.

15. National Research Council, Washington DC (2005). Mineral Tolerance of Domestic Animals.

16. Rashid H, Fardous Z, Chowdhury MAZ and Alam K (2016). Determination of heavy metals in the soils of tea plantations and in fresh and processed tea leaves : an evaluation of six digestion methods. Chemistry Central Journal 10: 1-13.

17. Sunda PN (2010). Are we eating chrome chicken? The Socioscan 2: 69-77. 